\title{
Anti-CD19 Monoclonal Antibody DI-B4
}

National Cancer Institute

\section{Source}

National Cancer Institute. Anti-CD19 Monoclonal Antibody DI-B4. NCI Thesaurus. Code C105805.

A low-fucosylated, humanized, IgG1 isotype, monoclonal antibody directed ag ainst the Bcell-specific membrane protein CD19 with potential immunostimulating and antineoplastic activities. Anti-CD19 monoclonal antibody DI-B4 binds to CD19, which may result in a strong antibody-dependent cellular cytotoxicity (ADCC) directed at CD19expressing B-cells but with minimal complement dependent cytotoxicity. DI-B4 contains low levels of fucose, which contributes to its enhanced ADCC activity. CD19 is a B-cell specific membrane antigen that is widely expressed during B-cell development and in all B-cell lineage malignancies. 